Bul. Agrohorti 3 (3) : 285 - 293 (2015)

\title{
Pengelolaan Pemangkasan Tanaman Kakao (Theobroma Cacao L.) Di Cilacap, Jawa Tengah
}

Pruning Management of Cacao (Theobroma cacao L.) in Cilacap, Central Java

\author{
Angela dan Darda Efendi* \\ Departemen Agronomi dan Hortikultura, Fakultas Pertanian, Institut Pertanian Bogor \\ (Bogor Agricultural University), J1. Meranti, Kampus IPB Darmaga, Bogor 16680, Indonesia \\ Telp. \& Faks. 62-251-8629353 e-mail agronipb@indo.net.id \\ *Penulis Korespondensi : dardaefendi@yahoo.com/darda@ipb.ac.id
}

Disetujui : 14 November 2015 / Published online 12 Desember 2015

\begin{abstract}
The research activity was held in Cilacap, Central Java started from 14th February until 14th June 2011. The purpose of this research is to know, learn, and analyze the pruning management of cacao that carried out in field. The activity include the technical and managerial aspects that consists of as field worker for one month, as assistant foreman for one month, and as assistant field lead for two month. The primary data obtained from all activities undertaken during the research and direct observations in the field while the secondary data obtained from company reports. Pruning is done during the research is maintenance pruning that is influenced by the success of pruning. Pruning activity affect the amount of chupon, flowering cushions, and the resistance cherelle and cocoa pods to pests and diseases. Pruning rotation also affects the stability of year-round production of cocoa beans.
\end{abstract}

Keywords: cherelle, chupon, cocoa, production, pruning

\begin{abstract}
ABSTRAK
Penelitian ini berlangsung di daerah Cilacap, Jawa Tengah mulai dari 14 Februari sampai 14 Juni 2011. Tujuan penelitian ini yaitu untuk pengetahuan, pembelajaran dan memahami manajemen pemangkasan kakao di kebun. Aktivitas penelitian terdiri atas teknikal dan aspek manajerial yaitu sebagai karyawan harian lepas selama satu bulan, asisten mandor selama satu bulan, dan sebagai pendamping asisten afdeling selama dua bulan. Data primer diperoleh dari semua aktivitas penelitian dan pengamatan langsung di lapang, sedangkan data sekunder diperoleh dari catatan laporan perusahaan. Pemangkasan yang dilakukan selama penelitian yaitu pemangkasan pemeliharaan. Pemangkasan mempengaruhi jumlah tunas air, bantalan yang berbunga, ketahanan cherelle (pentil buah) dan buah terhadap hama dan penyakit tanaman. Rotasi pemangkasan juga mempengaruhi kestabilan produksi biji tahunan kakao.
\end{abstract}

Kata kunci: kakao, pemangkasan, pentil buah, produksi, tunas air 


\section{PENDAHULUAN}

Kakao merupakan salah satu komoditi perkebunan utama andalan nasional. Sejak awal tahun 1980-an, pertumbuhan dan perkembangan kakao semakin pesat di Indonesia dan berperan penting sebagai sumber devisa negara, sumber pendapatan petani, serta penyediaan lapangan pekerjaan. Kondisi iklim, kondisi lahan dan permintaan terhadap kakao mendorong meningkatnya pembangunan perkebunan kakao Indonesia (Pusat Penelitian Kopi dan Kakao Indonesia, 2004).

Luas areal produksi kakao di Indonesia tahun 2009 sebesar 1587136 ha dengan $94 \%$ luas areal adalah perkebunan rakyat. Total produksi biji kakao Indonesia untuk tahun 2009 sebesar 809583 ton (Ditjenbun, 2011) dan pada tahun 2009, Indonesia berada di peringkat kedua setelah Pantai Gading (Cote d'Ivore) sebagai negara produsen kakao dunia (FAO, 2011).

Kakao merupakan komoditas yang mampu memberikan penghasilan yang cukup baik dan terus menerus sepanjang tahun bagi masyarakat petani kakao. Penanaman kakao tidak harus monokultur dalam budidayanya, tetapi dapat ditanam bersama dengan tanaman lain sebagai tumpangsari ataupun dengan tanaman penaung sehingga petani memperoleh keuntungan ganda (Baon dan Abdoellah, 2004). Namun, saat ini produktivitas tanaman kakao rata-rata baru mencapai $591.18 \mathrm{~kg} / \mathrm{ha}$ sedangkan potensi produktivitas dapat mencapai $1.5-3$ ton/ha (Kardiyono, 2010). Untuk menjaga agar produktivitas kakao meningkat dapat dilakukan pemeliharaan tanaman yang salah satu aspeknya adalah pemangkasan.

Pemangkasan merupakan suatu tindakan yang dilakukan perkebunan kakao untuk mengoptimalkan nilai LAI (Leaf Area Indeks) dan mengutamakan ranting sebagai obyek pemangkasan (Soedarsono, 1996) sehingga tanaman kakao dapat berproduksi baik dan terus menerus. Pengaruh pemangkasan pada tanaman kakao berdampak besar, yaitu menurunkan kelembaban kebun, memperoleh iklim mikro yang sehat dan produksi tinggi, serta pemangkasan yang efektif dan tepat waktu dapat membantu pengontrolan penyakit tanaman kakao (Wood and Lass, 1985). Pemangkasan pada tanaman kakao antara lain pemangkasan bentuk untuk membentuk kerangka tanaman, pemangkasan pemeliharaan untuk mempertahankan kerangka dan membuang cabang sakit, serta pemangkasan produksi yang bertujuan untuk memacu pertumbuhan bunga dan buah (Pusat Penelitian Kopi dan Kakao Indonesia, 2004).

Penelitian ini dilakukan untuk mengetahui, mempelajari dan menganalisis pengelolaan pemangkasan tanaman kakao di salah satu perkebunan kakao di Cilacap, Jawa Tengah sehingga dapat memberikan manfaat timbal balik antara mahasiswa dan perusahaan.

\section{BAHAN DAN METODE}

Kegiatan penelitian dilaksanakan di salah satu perkebunan kakao di Cilacap, Jawa Tengah mulai 14 Februari sampai 14 Juni 2011.

Kegiatan penelitian yang dilakukan penulis meliputi aspek teknis budidaya dan aspek manajerial kebun. Metode pelaksanaan yang dilaksanakan adalah beberapa tingkat jabatan, yaitu selama satu bulan sebagai Karyawan Harian Lepas (KHL), pendamping mandor selama satu bulan, dan pendamping asisten afdeling selama dua bulan.

Data primer yang berkaitan dengan kegiatan pemangkasan selama penelitian antara lain:

Jenis Pemangkasan. Mengamati jenis pemangkasan yang dilakukan di kebun kakao selama bulan Februari hingga Juni 2011.

Alat Pangkas. Mengamati alat pangkas yang digunakan oleh pemangkas dan yang paling efisien untuk pemangkasan. Pengambilan sampel 7 orang pemangkas yang menggunakan cungkring dan golok, serta 3 orang pemangkas yang menggunakan gergaji pangkas dan golok.

Waktu Pemangkasan. Berkaitan dengan rotasi pemangkasan dan kesesuaian waktu pemangkasan dengan perencanaan kegiatan.

Luas Areal Pemangkasan. Menghitung luas areal pemangkasan yang dikerjakan oleh satu orang pemangkas dalam satu hari.

Prestasi Kerja Pemangkasan, Menghitung jumlah tanaman yang dapat dipangkas oleh satu orang pemangkas dalam sehari.

Keberhasilan Pemangkasan. Mengambil sampel 10 orang pemangkas dengan pengelompokkan berdasarkan usia dan jenis kelamin. Jumlah pohon sebagai ulangan untuk keberhasilan pemangkasan. Berdasarkan usia yaitu 4 orang pemangkas berusia 16-35 tahun dan 6 orang pemangkas berusia $\geq 36$ tahun. Berdasarkan jenis kelamin yaitu 5 orang pemangkas laki-laki dan 5 orang pemangkas perempuan.

Pembagian kriteria untuk alat pangkas, usia, dan jenis kelamin pemangkas mengikuti kriteria pengamatan Arifin (2007) dan Ermayasari 
(2010) sehingga dapat diperbandingkan. Pengambilan sampel jumlah orang yang berbeda berdasarkan jumlah tenaga kerja yang sesuai dengan kriteria yang terdapat di lapang.

Pemangkasan pada kakao berkaitan erat dengan produksi yang dihasilkan, maka dilakukan pengambilan data dari perusahaan mengenai rotasi pemangkasan yang dilakukan dan produksi yang dihasilkan pada Blok A6 dan A8 dari tahun 2007 hingga 2010. Selain itu, dilakukan pula pengamatan antara tanaman yang dipangkas dan tanaman yang tidak dipangkas masing-masing sebanyak 15 tanaman untuk diamati jumlah tunas air, bantalan yang berbunga, cherelle (pentil buah), dan perkembangan buah dari ukuran 1 sampai ukuran 4 yang dihasilkan setelah dilakukan pemangkasan. Pengamatan dilakukan satu minggu sekali selama 6 minggu.

Data sekunder lainnya adalah peta lokasi, data curah hujan dan kondisi umum perusahaan, struktur organisasi perusahaan, keadaan tanaman, data produksi serta data lain yang menunjang. Analisis data untuk aspek pemangkasan dapat dilihat dari keberhasilan pemangkasan yang meliputi pengamatan jumlah cabang yang dipangkas dan jumlah cabang yang kulitnya rusak karena pemangkasan. Perhitungan keberhasilan pemangkasan menggunakan rumus berikut.

\section{Keberhasilan pemangkasan $(\%): \frac{\Sigma a+\Sigma b+\Sigma c+\Sigma d)}{\Sigma a+\Sigma b+\Sigma c+\Sigma d} \times 100$}

\section{Keterangan :}

$\Sigma \mathrm{a}:$ jumlah cabang berdiameter kurang dari $2.5 \mathrm{~cm}$ yang dipangkas

$\Sigma b$ : jumlah cabang sakit yang dipangkas

$\Sigma c$ : jumlah cabang kering yang dipangkas

$\Sigma \mathrm{d}$ : jumlah cabang berdiameter kurang lebih $2.5 \mathrm{~cm}$ yang dipangkas

$\Sigma$ e : jumlah cabang yang kulitnya rusak akibat pemangkasan (Arifin, 2007)

Selanjutnya data dihitung dengan menggunakan analisis stastistik sederhana yaitu rata-rata dari keberhasilan pemangkasan berdasarkan perbedaan usia, jenis kelamin pemangkas, serta alat pangkas yang digunakan. Kemudian dibandingkan dengan nilai keberhasilan pemangkasan beberapa tahun sebelumnya untuk mengetahui kemungkinan terjadinya peningkatan atau penurunan dengan menggunakan software statistik SAS untuk uji $t$ student. Kemudian dari data rotasi pemangkasan dan curah hujan serta produksi antara tanaman yang dipangkas dan tidak dipangkas akan dianalisis secara deskriptif pengaruh dilakukannya pemangkasan terhadap produksi kakao di Kebun Cilacap, Jawa Tengah.

Perkebunan terletak pada ketinggian 20$90 \mathrm{~m}$ dpl dengan jenis tanah podzolik merah kuning, topografi berombak sampai bergelombang, lereng $0-10 \%$, dengan $\mathrm{pH}$ tanah berkisar antara 5.0 hingga 6.2. Rata-rata curah hujan tahun 2000-2010 sebesar $2550.05 \mathrm{~mm} / \mathrm{thn}$ dengan rata-rata bulan basah 7.9 bulan dan bulan kering 3 bulan. Berdasarkan klasifikasi SchmidthFergusson kebun kakao ini termasuk tipe iklim C.

Luas areal perkebunan adalah 1050.268 ha dengan komoditas yang diusahakan adalah kakao (TM) seluas 465.911 ha yang terbagi menjadi 3 afdeling yaitu afdeling $\mathrm{A}, \mathrm{B}$, dan $\mathrm{C}$. Tipe kakao yang ditanam Perkebunan adalah tipe Criollo dan Forastero. Bahan tanam berupa benih hibrida mulai dari tahun 1990 hingga 1994. Jarak tanam kakao yang digunakan adalah $3 \mathrm{~m}$ x $2.5 \mathrm{~m}$. Populasi tanaman kakao secara keseluruhan pada tahun 2011 hanya 271523 tanaman yaitu $43.72 \%$ dari populasi normal. Penurunan jumlah populasi tanaman kakao disebabkan oleh banyaknya tanaman yang telah tidak produktif, kering, atau mati sehingga dilakukan penebangan. Rata-rata produksi biji kakao kering dari tahun 2004-2010 adalah $423188 \mathrm{~kg}$ dengan produktivitas 610.92 $\mathrm{kg} \mathrm{ha}^{-1}$.

\section{HASIL DAN PEMBAHASAN}

Pemangkasan merupakan salah satu teknik budidaya yang penting dilakukan dalam pemeliharaan tanaman kakao dengan cara membuang tunas-tunas liar seperti cabang-cabang yang tidak produktif, cabang sakit, cabang kering, dan cabang overlapping terutama dalam hal mengatur iklim mikro yang tepat bagi pertumbuhan bunga dan buah atau untuk mengatur jumlah dan sebaran daun (Prawoto, 2008) sehingga tanaman kakao dapat memiliki kondisi yang baik untuk pertumbuhannya.

\section{Jenis dan Waktu Pemangkasan}

Jenis pemangkasan untuk tanaman kakao terbagi menjadi tiga yaitu pemangkasan bentuk, pemeliharaan, dan produksi. Pemangkasan bentuk 
dilakukan untuk membentuk kerangka tanaman yang baik. Pemangkasan pemeliharaan bertujuan untuk memelihara tanaman kakao agar pertumbuhannya dapat bertahan dengan baik dan sehat, sedangkan pemangkasan produksi untuk memaksimalkan produktivitas tanaman. Tanaman kakao di salah satu Kebun kakao di Cilacap merupakan tanaman yang telah menghasilkan sehingga kegiatan pemangkasan yang masih dilakukan setiap tahunnya adalah pemangkasan pemeliharaan dan pemangkasan produksi.

Pemangkasan pemeliharaan dilakukan untuk membuang cabang cacing, cabang yang terkena penyakit, dan cabang menggantung. Pemangkasan pemeliharaan sebaiknya merupakan pemangkasan yang ringan tetapi sering karena cabang yang dibuang adalah cabang yang berdiameter kurang dari $2.5 \mathrm{~cm}$. Frekuensi pemangkasan pemeliharaan sebaiknya dilakukan setiap 2-3 bulan sedangkan di Kebun kakao ini memiliki rotasi rata-rata tiga kali dalam satu tahun. Sedangkan pemangkasan produksi merupakan pemangkasan berat karena untuk merangsang pertumbuhan bunga dan buah. Pemangkasan produksi di Kebun kakao ini hanya dilakukan satu kali dalam setahun yaitu pada awal musim hujan sekitar bulan November atau Desember.

Pemangkasan pemeliharaan sebaiknya menghindari pemotongan cabang dengan diameter lebih dari $2.5 \mathrm{~cm}$. Apabila terpaksa dilakukan pemotongan cabang besar maka perlu meninggalkan sisa cabang sepanjang $5 \mathrm{~cm}$ (Pusat Penelitian Kopi dan Kakao Indonesia, 2004). Pemangkasan pemeliharaan di salah satu Kebun kakao di Cilacap mengalami keterlambatan karena banyak cabang dengan diameter lebih dari $2.5 \mathrm{~cm}$ yang dipangkas sehingga pemangkasan yang dilakukan adalah pemangkasan berat dan seolah terlihat sebagai pemangkasan produksi.

\section{Luas Areal dan Prestasi Kerja Pemangkasan}

Standar perusahaan untuk pemangkasan pemeliharaan adalah $4 \mathrm{HK} \mathrm{ha}^{-1}$ sedangkan untuk pemangkasan produksi adalah $6 \mathrm{HK}^{\mathrm{ha}^{-1}}$. Berdasarkan hasil kalibrasi untuk kegiatan pemangkasan pemeliharaan, rata-rata satu orang tenaga kerja dapat memangkas 122 pohon dalam satu hari kerja. Prestasi kerja pemangkasan pada Tabel 1, dipengaruhi oleh kondisi tenaga kerja, lahan, dan keadaan tanaman.

Tabel 1. Prestasi kerja pemangkas

\begin{tabular}{ccc}
\hline Blok & Standar Perusahaan & Prestasi Kerja \\
\hline & & $----H a / H K---$ \\
C5 & 0.25 & 0.31 \\
C9 & 0.25 & 0.14 \\
\hline
\end{tabular}

\section{Keberhasilan Pemangkasan}

Kegiatan pemangkasan tidak terlepas dari keterampilan pemangkas dan peralatan yang digunakan. Kurangnya keterampilan pemangkas dapat menyebabkan menurunnya prestasi kerja karena pemangkas kurang mengetahui cabang mana yang harus dipangkas dan tidak dipangkas dan menyebabkan waktu yang digunakan untuk pemangkasan tidak optimal. Selanjutnya, alat pangkas yang digunakan di Kebun kakao di Cilacap adalah cungkring dan gergaji pangkas yang keduanya disambungkan dengan bambu panjang (galah) sehingga dapat menjangkau cabang yang tinggi. Namun, banyak tanaman kakao di Kebun kakao di Cilacap yang tingginya melebihi 3-4 $\mathrm{m}$ dan menyebabkan pemangkas sulit menjangkau cabang sakit atau cabang kering yang terdapat di pucuk tanaman karena keterbatasan tinggi pemangkas dan panjang alat pangkas. Akhirnya pemangkas harus memanjat tanaman kakao terlebih dahulu untuk memangkas cabang sakit atau cabang kering di bagian pucuk.
Sebelum pemangkasan, ketajaman alat juga merupakan hal penting yang harus dilakukan karena alat yang kurang tajam dapat dan dapat menyebabkan kerusakan kulit pada batang. Rusaknya kulit cabang akibat pemangkasan berpengaruh terhadap keberhasilan pemangkasan. Kulit cabang yang terkelupas dan luka akan memerlukan waktu lama dalam pemulihannya bahkan dapat menimbulkan resiko masuknya jamur patogen melalui luka potongan dan sebaiknya luka tersebut diolesi dengan obat penutup luka (Soedarsono, 1996). Semakin besar jumlah kulit cabang rusak maka persentase keberhasilan pemangkasan semakin kecil.

Keberhasilan pemangkasan yang dilakukan saat pengamatan di lapang dikelompokkan berdasarkan jenis kelamin, usia, dan alat yang digunakan. Jenis kelamin terbagi menjadi pemangkas berjenis kelamin pria atau wanita. Usia terbagi menjadi pemangkas berusia 16-35 tahun dan pemangkas berusia $\geq 36$ tahun. Peralatan yang digunakan yaitu cungkring dan golok serta gergaji pangkas dan golok. Kriteria tersebut mengikuti pengamatan Arifin pada tahun 
2007 dan Ermayasari pada tahun 2009 sehingga hasil pengamatan dapat diperbandingkan.

Jenis Kelamin. Berdasarkan jenis kelamin, pemangkas dibedakan antara pria dan wanita. Rata-rata keberhasilan pemangkasan pria memiliki nilai sebesar $92.01 \%$, lebih besar 6.71
\% dibandingkan dengan pemangkas berjenis kelamin wanita. Setelah dilakukan uji $t$-student pada Tabel 2, diperoleh bahwa jenis kelamin tidak memberikan pengaruh yang berbeda nyata pada taraf $5 \%$ sehingga sama saja dalam penggunaan tenaga pemangkas antara pria atau wanita.

Tabel 2. Pengaruh jenis kelamin terhadap keberhasilan pemangkasan

\begin{tabular}{llcc}
\hline Jumlah Pemangkas & Kelamin Jenis & $\begin{array}{c}\text { Jumlah tanaman } \\
\text { sampel }\end{array}$ & Rata-rata Keberhasilan Pemangkasan (\%) \\
\hline 5 & Pria & 25 & $92.01 \mathrm{a}$ \\
5 & Wanita & 25 & $85.30 \mathrm{a}$ \\
\hline \multicolumn{2}{l}{ Keterangan : Angka yang diikuti huruf yang sama pada kolom yang sama menunjukkan nilai tidak berbeda nyata berdasarkan uji } \\
\multicolumn{2}{l}{-student taraf 5\% }
\end{tabular}

Usia. Selain jenis kelamin, keberhasilan pemangkasan juga didasarkan pada usia pemangkas yang dibedakan antara usia 16-35 tahun dan usia $\geq 36$ tahun. Hasil yang diperoleh dari Tabel 3 memperlihatkan bahwa pemangkas dengan usia 16-35 tahun memiliki nilai rata-rata keberhasilan pemangkasan sebesar $91.42 \%$ dan lebih besar dibanding pemangkas usia $\geq 36$ tahun dengan rata-rata keberhasilan pemangkasan 86.80 $\%$. Namun, melalui uji $t$-student, perbedaan usia tidak memberikan pengaruh yang berbeda nyata pada taraf $5 \%$ yang berarti usia tidak mempengaruhi keberhasilan pemangkasan.

Tabel 3. Pengaruh usia terhadap keberhasilan pemangkasan

\begin{tabular}{cccc}
\hline Jumlah pemangkas & Usia (tahun) & Jumlah tanaman sampel & $\begin{array}{c}\text { Rata-rata keberhasilan } \\
\text { pemangkasan }\end{array}$ \\
\hline 4 & $16-35$ & 20 & $91.42 \mathrm{a}$ \\
6 & $\geq 35$ & 30 & $86.80 \mathrm{a}$ \\
\hline Keterangan : Angka yang diikuti huruf .ang sama pada kolom yang sama menunjukkan nilai tidak berbeda nyata berdasarkan uji
\end{tabular}

Keterangan : Angka yang diikuti huruf yang sama pada kolom yang sama menunjukkan nilai tidak berbeda nyata berdasarkan uji $t$-student taraf $5 \%$

Alat pangkas. Tabel 4 membedakan keberhasilan pemangkasan berdasarkan alat pangkas yang digunakan yaitu antara penggunaan cungkring dan golok serta gergaji pangkas dan golok. Berdasarkan Tabel 4, dapat dilihat bahwa penggunaan gergaji pangkas lebih baik $5.77 \%$ dibanding dengan penggunaan cungkring dan golok, tetapi penggunaan alat pangkas yang berbeda tidak memberikan pengaruh yang berbeda nyata pada uji t taraf $5 \%$.

Tabel 4. Pengaruh alat pangkas terhadap keberhasilan pemangkasan

\begin{tabular}{clcc}
\hline Jumlah pemangkas & \multicolumn{1}{c}{ Alat pangkas } & Jumlah tanaman sampel & $\begin{array}{c}\text { Rata-rata keberhasilan } \\
\text { pemangkasan }(\%)\end{array}$ \\
\hline 7 & Cungkring dan golok & 35 & $86.92 \mathrm{a}$ \\
3 & Gergaji pangkas dan golok & 15 & $92.69 \mathrm{a}$ \\
\hline
\end{tabular}

Keterangan : Angka yang diikuti huruf yang sama pada kolom yang sama menunjukkan nilai tidak berbeda nyata berdasarkan uji $t$-student taraf $5 \%$

Jenis Kelamin dan Usia. Secara keseluruhan antara hubungan jenis kelamin dan usia seperti pada Tabel 5 dapat dilihat keberhasilan pemangkasan antara jenis kelamin pria dan wanita dengan usia 16-35 tahun dan $\geq 36$ tahun. Pemangkas berjenis kelamin pria dengan usia $\geq 36$ tahun memberikan nilai rata-rata keberhasilan pemangkasan yang tertinggi yaitu sebesar $92.69 \%$ dan pemangkas berjenis kelamin wanita dengan usia $\geq 36$ tahun dengan nilai ratarata keberhasilan pemangkasan $80.92 \%$ merupakan yang terendah dan memberikan pengaruh yang berbeda nyata pada taraf $5 \%$ berdasarkan hasil uji t. 
Tabel 5. Keberhasilan pemangkasan berdasarkan hubungan jenis kelamin dan usia

\begin{tabular}{clccc}
\hline Jumlah Pemangkas & Jenis kelamin & Usia (tahun) & $\begin{array}{c}\text { Jumlah tanaman } \\
\text { sampel }\end{array}$ & $\begin{array}{c}\text { Rata-rata keberhasilan } \\
\text { pemangkasan }(\%)\end{array}$ \\
\hline 2 & Pria & $16-35$ & 10 & $90.98 \mathrm{a}$ \\
3 & Pria & $\geq 36$ & 15 & $92.69 \mathrm{a}$ \\
2 & Wanita & $16-35$ & 10 & $91.86 \mathrm{a}$ \\
3 & Wanita & $\geq 36$ & 15 & $80.92 \mathrm{~b}$ \\
\hline
\end{tabular}

Keterangan : Angka yang diikuti huruf yang sama pada kolom yang sama menunjukkan nilai tidak berbeda nyata berdasarkan uji $t$-student taraf $5 \%$

Perbandingan Pengamatan. Selain pengamatan secara langsung, keberhasilan pemangkasan yang diamati penulis juga dibandingkan dengan pengamatan beberapa tahun sebelumnya yaitu berdasarkan pengamatan Arifin pada tahun 2007 dan pengamatan Ermayasari pada tahun 2009. Berikut adalah Tabel 6 untuk perbandingan hasil pengamatan keberhasilan pemangkasan.

Hasil pengamatan rata-rata keberhasilan pemangkasan untuk pemangkas berjenis kelamin pria mengalami penurunan pada pengamatan
Ermayasari kemudian meningkat pada pengamatan penulis dengan selisih $3.01 \%$, namun uji $\mathrm{t}$ memberikan hasil tidak adanya pengaruh berbeda nyata untuk keberhasilan pemangkasan pria. Sedangkan rata-rata keberhasilan pemangkasan untuk pemangkas berjenis kelamin wanita mengalami penurunan dan setelah dilakukan uji $\mathrm{t}$ diperoleh bahwa pengamatan Ermayasari dan Penulis memberikan pengaruh berbeda nyata pada taraf $5 \%$ dibandingkan dengan pengamatan Arifin.

Tabel 6. Perbandingan data hasil pengamatan untuk keberhasilan pemangkas

\begin{tabular}{|c|c|c|c|c|c|c|}
\hline & \multicolumn{6}{|c|}{ Keberhasilan Pemangkasan (\%) } \\
\hline & \multicolumn{2}{|c|}{ Jenis Kelamin } & \multicolumn{2}{|c|}{ Usia } & \multicolumn{2}{|c|}{ Alat } \\
\hline Pengamat & Pria & Wanita & $16-35$ & $\geq 36$ & $\begin{array}{c}\text { Cungkring dan } \\
\text { golok }\end{array}$ & $\begin{array}{c}\text { Gergaji } \\
\text { pangkas dan } \\
\text { Golok }\end{array}$ \\
\hline Arifin & & & & & - & - \\
\hline Ermayasari & $89.00 \mathrm{a}$ & $85.60 \mathrm{~b}$ & - & - & $79.76 \mathrm{a}$ & $87.90 \mathrm{a}$ \\
\hline Penulis & $92.01 \mathrm{a}$ & $85.30 \mathrm{~b}$ & $91.42 \mathrm{a}$ & $86.80 \mathrm{a}$ & $86.92 a$ & $92.69 \mathrm{a}$ \\
\hline
\end{tabular}

Sumber : Hasil Pengamatan, Data Pengamatan Arifin (2007) dan Ermayasari (2010)

Keterangan : Angka yang diikuti huruf yang sama pada kolom yang sama menunjukkan nilai tidak berbeda nyata berdasarkan uji $t$-student taraf 5\%

Hasil pengamatan rata-rata keberhasilan pemangkasan untuk pemangkas berjenis kelamin pria mengalami penurunan pada pengamatan Ermayasari kemudian meningkat pada pengamatan penulis dengan selisih $3.01 \%$, namun uji $\mathrm{t}$ memberikan hasil tidak adanya pengaruh berbeda nyata untuk keberhasilan pemangkasan pria. Sedangkan rata-rata keberhasilan pemangkasan untuk pemangkas berjenis kelamin wanita mengalami penurunan dan setelah dilakukan uji $\mathrm{t}$ diperoleh bahwa pengamatan Ermayasari dan Penulis memberikan pengaruh berbeda nyata pada taraf $5 \%$ dibandingkan dengan pengamatan Arifin.

Kriteria usia hanya diamati oleh Arifin dan Penulis yaitu usia 16-35 tahun dan $\geq 36$ tahun. Data pada Tabel 5, dapat dilihat bahwa usia 16-35 tahun mengalami peningkatan keberhasilan pemangkasan sebesar $1.79 \%$, sedangkan usia $\geq 36$ tahun mengalami penurunan tetapi kedua kriteria dari kedua pengamatan tidak memberikan pengaruh yang berbeda nyata pada uji $\mathrm{t}$ dengan taraf $5 \%$.

Keberhasilan pemangkasan berdasarkan alat pangkas yang digunakan yaitu cungkring dan golok serta gergaji pangkas dan golok, keduanya mengalami peningkatan rata-rata keberhasilan pemangkasan. Penggunaan cungkring dan golok sebagai alat pangkas mengalami peningkatan nilai rata-rata keberhasilan pemangkasan sebesar 7.16 $\%$. Penggunaan geraji pangkas dan golok memberikan peningkatan rata-rata keberhasilan pemangkasan sebesar $4.79 \%$. Namun berdasarkan uji t, pemangkasan dengan menggunakan cungkring dan golok serta gergaji pangkas dan golok tidak memberikan pengaruh yang berbeda nyata pada kedua pengamatan tersebut.

\section{Pengaruh Rotasi Pemangkasan dan Curah Hujan terhadap Produksi}

Pemangkasan juga merupakan salah satu kegiatan yang dilakukan dalam pemeliharaan kakao untuk memperoleh produksi yang tinggi 
dan optimum. Pengaruh rotasi pemangkasan terhadap produksi kakao juga dapat dilihat pada Gambar 1 dan Gambar 2. Rotasi pangkas A6 pada tahun 2007 adalah tiga kali setahun yaitu dua pemangkasan pemeliharaan pada bulan Februari dan Juni serta satu pemangkasan produksi pada bulan Desember. Produksi pada tahun 2008 untuk A6 seperti pada Gambar 1 terdapat dua kali kenaikan yaitu pada bulan Maret hingga Mei dan bulan Agustus.

Pemangkasan di tahun 2008 untuk A6 memiliki tiga kali pemangkasan pemeliharaan pada bulan Februari, April, dan Juni serta satu pemangkasan produksi di bulan Desember. Produksi di tahun 2009 pada Gambar 1 menunjukkan grafik yang tidak stabil dan terdapat penurunan yang signifikan dari bulan Mei ke Juni.

Pemangkasan di tahun 2009 di A6 dilakukan tiga kali pemangkasan pemeliharaan di bulan Januari, Maret, dan Mei serta satu pemangkasan produksi di bulan November. Hasil biji cokelat basah di tahun 2010 untuk A6 mengalami dua kali kenaikan yaitu di bulan Mei dan Juli kemudian menurun hingga akhir tahun. Sedangkan A8 (Gambar 2) pada tahun 2007 memiliki rotasi pemangkasan empat kali setahun yaitu pemangkasan pemeliharaan pada bulan Januari, Mei, dan Juli serta pemangkasan produksi pada bulan Desember. Produksi A8 pada tahun 2008 memperlihatkan kenaikan pada bulan April kemudian stabil hingga bulan September dan tidak menunjukkan peningkatan atau penurunan yang drastis walau produksi masih lebih rendah daripada tahun 2007.

Tahun 2008, terdapat satu pemangkasan pemeliharaan di bulan Februari dan pemangkasan produksi di bulan Desember yang dilakukan di A8 dan produksi di tahun 2009 terjadi kenaikan di bulan Maret hingga Mei dan Oktober. Bulan Februari dan Mei tahun 2009 di A8 dilakukan pemangkasan pemeliharaan dan di bulan November dilakukan pemangkasan produksi. Produksi di A8 hanya mengalami kenaikan di bulan Mei. Penurunan produksi walau terlihat stabil tetapi lebih rendah dibanding tahun sebelumnya.

Pengaruh peningkatan produksi dapat terlihat rata-rata dua bulan setelah dilakukannya pemangkasan pemeliharaan dan sekitar 5-6 bulan setelah dilakukan pemangkasan produksi. Hal ini sesuai pada perkembangan bunga kakao hingga menjadi buah masak yang memerlukan waktu sekitar 5-6 bulan (Prawoto, 2008).

Pemangkasan pemeliharaan dan produksi seperti yang terlihat pada Gambar 1 dan Gambar 2 biasanya dilakukan pada saat curah hujan tinggi atau pun di akhir musim hujan. Hal ini dilakukan untuk menghindari kekeringan atau kematian tanaman kakao apabila pemangkasan dilakukan saat curah hujan rendah ataupun musim kemarau. Secara deskriptif, produksi yang terlihat beberapa bulan setelah pemangkasan yang dilakukan saat curah hujan tinggi memberikan hasil produksi yang lebih tinggi dibandingkan dengan produksi dari pemangkasan yang dilakukan saat akhir musim hujan atau curah hujan rendah.

Sumber : Arsip kantor salah satu kebun kakao di Cilacap untuk rotasi pemangkasan dan produksi (2011)

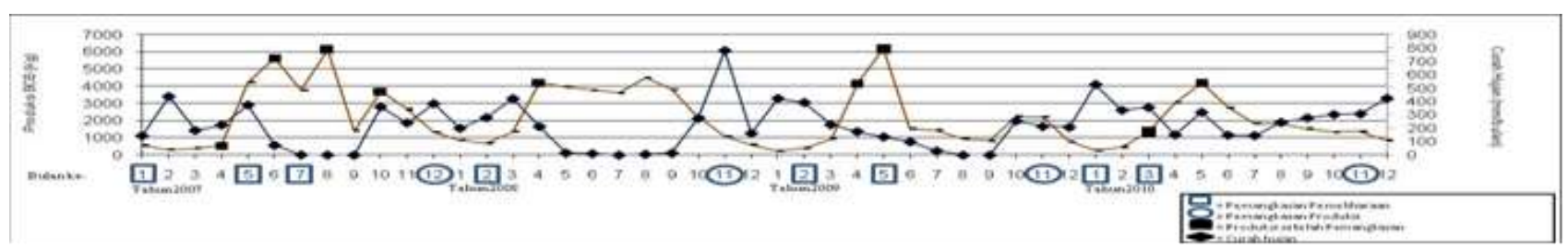

Gambar 1. Rotasi pemangkasan dan produksi afdeling A blok 6 di salah satu kebun kakao di Cilacap Tahun 2007-2010

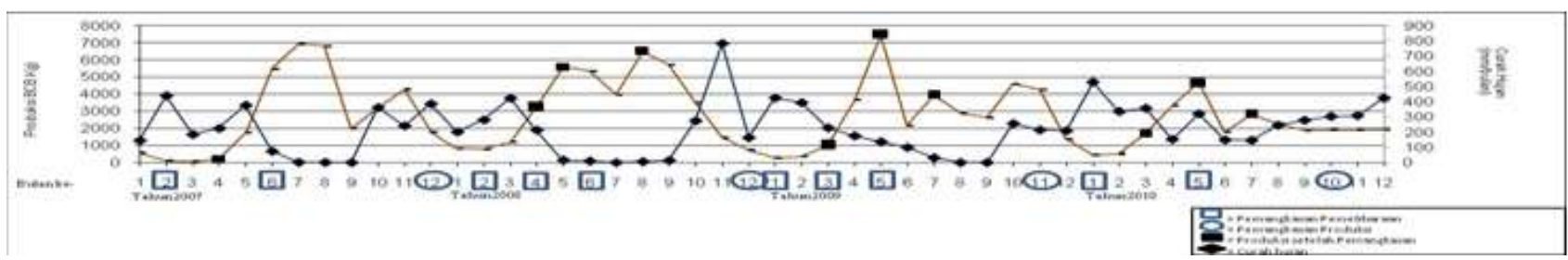

Sumber : Arsip kantor salah satu kebun kakao di Cilacap untuk rotasi pemangkasan dan produksi (2011)

Gambar 2. Rotasi pemangkasan dan produksi afdeling A blok 8 di salah satu kebun kakao di Cilacap Tahun 2007-2010

\section{Pengamatan Perlakuan Pemangkasan}

Pengaruh pemangkasan juga dapat dilihat dari jumlah tunas air, bantalan yang berbunga, pentil buah, dan perkembangan buah antara pohon yang dipangkas dan tidak dipangkas. Tunas air pada tanaman yang dipangkas pada minggu pertama memiliki jumlah lebih rendah dibanding tanaman yang tidak dipangkas tetapi pada minggu terakhir pengamatan, tunas air tanaman yang dipangkas lebih banyak daripada tanaman yang tidak dipangkas seperti pada Gambar 3. Hal ini 
karena banyaknya pemotongan cabang besar akan mendorong tanaman kakao membentuk lebih banyak tunas air (Soedarsono, 1996). Oleh karena itu, adanya kegiatan wiwilan untuk membuang tunas air agar dapat mengurangi persaingan unsur hara antara tunas air dan pertumbuhan bunga serta buah.

Bantalan bunga pada tanaman kakao tidak semua yang menghasilkan bunga pada saat yang sama dan diharapkan setelah pemangkasan dapat merangsang pertumbuhan bunga. Oleh karena itu, pengamatan bantalan yang berbunga hanya dilakukan sebatas cabang primer. Bantalan berbunga pada tanaman yang tidak dipangkas lebih banyak pada minggu pertama dibanding tanaman yang dipangkas namun mengalami penurunan hingga minggu terakhir sedangkan bantalan yang berbunga pada tanaman yang dipangkas mengalami peningkatan yang perlahan (Gambar 3).

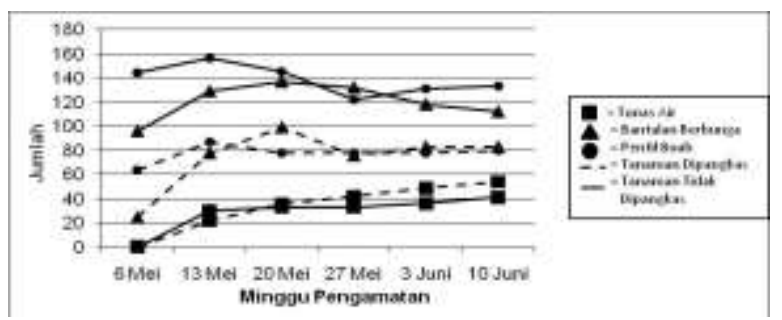

Gambar 3. Jumlah tunas air, bantalan berbunga dan pentil buah pada tanaman yang dipangkas dan tidak dipangkas

Pemangkasan yang benar sebaiknya melindungi cabang primer dari penyinaran matahari langsung karena dapat menyebabkan bantalan bunga menjadi mati. Hal ini yang mungkin terjadi pada minggu keempat sehingga jumlah bantalan berbunga pada tanaman yang dipangkas mengalami penurunan namun minggu berikutnya mengalami kenaikan karena adanya pertumbuhan bantalan berbunga yang baru. Menurunnya bantalan bunga pada tanaman yang tidak dipangkas dapat disebabkan persaingan unsur hara dengan daun-daun muda yang terbentuk.

Selain itu, bantalan bunga pada batang dan cabang tanaman kakao banyak yang tertutupi oleh lumut sehingga bunga sulit untuk tumbuh. Pertumbuhan lumut dapat disebabkan kondisi tanaman kakao yang basah dan lembap. Adanya pemangkasan dapat menambah intensitas cahaya yang masuk ke dalam tajuk dan menurunkan kelembapan di sekitar tanaman kakao dan lumut dapat mengering sehingga bantalan bunga dapat ditumbuhi kembali oleh bunga kakao.

Pengamatan untuk jumlah pentil buah pada tanaman yang dipangkas ataupun tidak dipangkas keduanya mengalami peningkatan pada minggu terakhir. Minggu kedua hingga keempat pada tanaman yang tidak dipangkas pentil buah mengalami penurunan jumlah dari 156 pentil buah pada minggu kedua menjadi 122 pentil buah pada minggu keempat dan mulai naik hingga minggu terakhir. Berkurangnya jumlah pentil buah dapat disebabkan terjadinya layu pentil (cherelle wilt) akibat persaingan dalam penyerapan hasil fotosintesis atau terjadi peralihan menjadi buah ukuran 1.

Pengamatan buah didasarkan pada ukuran atau ukuran panjang perkembangan buah yang terbagi menjadi ukuran $1(<10 \mathrm{~cm})$, ukuran 2 (10$15 \mathrm{~cm})$, ukuran $3(>16 \mathrm{~cm})$, dan ukuran 4 dengan ukuran panjang sama dengan ukuran 3 tetapi terdapat perubahan warna pada alur buah atau warna menjadi lebih kusam. Bahan tanam kakao yang digunakan di Kebun Rumpun Sari Antan I adalah hibrida sehingga ukuran dan bentuk buah berbeda antar pohon maka menentukan ukuran ukuran buah menggunakan perbandingan dengan ukuran buah terkecil pada pohon yang diamati.

Data dapat dilihat pada Gambar 4. Ukuran 1 dan ukuran 4 pada tanaman yang dipangkas atau pun tidak dipangkas keduanya mengalami penurunan pada minggu terakhir. Ukuran 2 dan ukuran 3 pada tanaman yang dipangkas mengalami peningkatan pada minggu terakhir dan pada tanaman yang tidak dipangkas mengalami penurunan. Jumlah buah pada awal pengamatan pada tanaman yang tidak dipangkas lebih banyak dibanding tanaman yang dipangkas. Peningkatan atau penurunan jumlah buah disebabkan peralihan ukuran buah, serangan hama dan penyakit, atau pemanenan pada buah ukuran 4 .

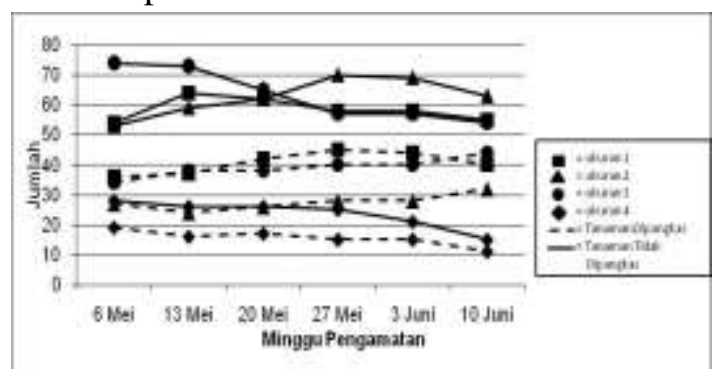

Gambar 4. Jumlah buah ukuran 1-4 pada tanaman yang dipamgkas dan tidak dipangkas

Perkembangan buah dari bunga hingga siap panen memerlukan waktu 5-6 bulan yang berarti rata-rata peralihan ukuran buah terjadi sekitar 1 bulan. Berdasarkan hasil pengamatan pada Gambar 5 memperlihatkan perkembangan buah terjadi lebih cepat pada tanaman yang dipangkas dibanding tanaman yang tidak dipangkas. 


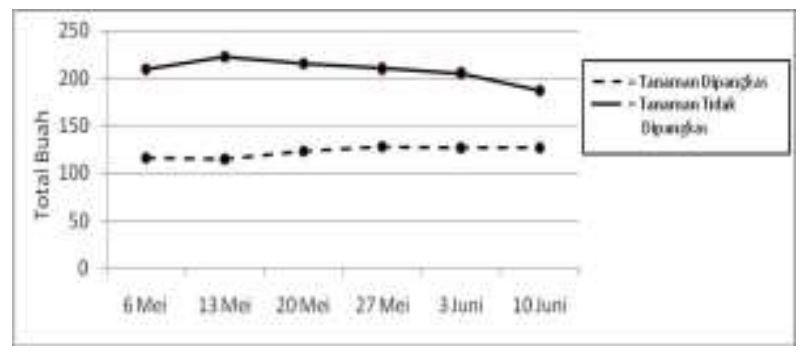

Gambar 5. Total buah ukuran 1-4 pada tanaman yang dipamgkas dan tidak dipangkas

\section{KESIMPULAN}

Jenis pemangkasan yang dilakukan selama Februari hingga Juni adalah pemangkasan pemeliharaan. Pemangkasan pemeliharaan di Kebun kakao di Cilacap dengan rotasi rata-rata tiga kali setahun dengan interval 2-5 bulan. Pemangkasan produksi yang dilakukan satu kali setahun sekitar bulan November atau Desember. Keberhasilan pemangkasan tidak berbeda nyata berdasarkan usia antara pemangkas berusia 16-35 tahun dan pemangkas berusia $\geq 36$ tahun, jenis kelamin antara pria dan wanita, serta alat pangkas antara cungkring dan gergaji pangkas. Sedangkan pemangkasan yang dilakukan oleh wanita berusia $\geq 36$ tahun keberhasilan pemangkasannya terendah dan berpengaruh berbeda nyata pada uji $t$-student taraf 5\%.

\section{DAFTAR PUSTAKA}

Arifin. 2007. Pengelolaan pemangkasan tanaman kakao (theobroma cacao 1.) di kebun $\mathrm{pt}$ rumpun sari antan i, pt sumber abadi tirtasantosa, Cilacap, Jawa Tengah. [skripsi]. Bogor (ID) : Institut Pertanian Bogor.

Baon, J. B., Abdoellah, S. 2004. Potensi lahan untuk pengembangan kakao rakyat Sumatera. Warta Pusat Penelitian Kopi dan Kakao 20(3):104-116.
[DITJENBUN] Direktorat Jenderal Perkebunan. 2011. Database [Internet]. [Diunduh 2011 Juli 4] Tersedia pada : http://ditjenbun.deptan.go.id/.

Ermayasari, I. W. 2009. Pengelolaan pemangkasan tanaman kakao (theobroma cacao 1.) di kebun pt rumpun sari antan i, pt sumber abadi tirtasantosa, Cilacap, Jawa Tengah [skripsi]. Bogor : Institut Pertanian Bogor.

[FAO] Food and Agriculture Organization of The United Nation . 2010. Database [Internet]. [Diunduh 2010 Des 5] Tersedia pada : http://faostat.fao.org .

Kardiyono. 2010. Tingkatkan produktivitas kakao dengan teknologi sambung samping. Surat Kabar Berkah Edisi 257.

Prawoto, A. A. 2008. Pemangkasan, hal. 123-127. Dalam T. Wahyudi, T.R. Panggabean, dan Pujiyanto (Eds.). Kakao: Manajemen Agribisnis dari Hulu hingga Hilir. Jakarta (ID) : Penebar Swadaya.

Pusat Penelitian Kopi dan Kakao Indonesia. 2004. Panduan Lengkap Budidaya Kakao. Jakarta (ID) : PT Agromedia Pustaka.

Soedarsono. 1996. Cara pemangkasan pada tanaman kakao. Warta Pusat Penelitian Kopi dan Kakao 12(3):178-186.

Wood, G.A.R., Lass, L.A. 1985. Cocoa. $4^{\text {th }}$ Edition. London (ENG) : Longman Group Lt. 